\title{
MULTIKULTURÁLIS IRODALOM REFLEKTÍV MEGKÖZELÍTÉSSEL: TRANSZFORMATÍV TANULÁSI ELMÉLET ALKALMAZÁSA A PEDAGÓGUSKÉPZÉSBEN
}

\section{SZÉCSI TÜNDE}

\author{
a Florida Gulf Coast University \\ egyetemi docense \\ tszecsi@fgcu.edu
}

\begin{abstract}
A tanulmány egy amerikai pedagógusképzöben alkalmazott multikulturális irodalmi projektet mutat be. A transzformatív tanulási elméletre épülö projekt lehetöséget adott a hallgatóknak arra, hogy a müvek olvasása közben és után, személyes reflexiókban (perszonális narrációban) kialakithassák saját véleményüket az adott kultúráról és az olvasottakról. A tanulmány elöször a projekt elméleti háttérét vázolja fel, majd a projekt alkalmazásának leírását és a hallgatók reflektív irásainak elemzését tartalmazza.
\end{abstract}

A pedagógusképzés egyik fontos feladata, hogy olyan tanárokat és tanítókat képezzen, akik képesek kialakítani egy olyan tanulási-tanítási környezetet, amelyet a befogadás, a másság, mint érték megközelítése és a tanulók egyéni igényének figyelembevétele és tisztelete jellemez. Az Európai Unió tanári kompetenciákról szóló dokumentuma is egyértelmüen felhívja a figyelmet az interkulturális kompetenciák fontosságára (European Commission, 2005). Ez a dokumentum kulcskompetenciaként emeli ki a kultúrák tiszteletét, a tanárok interkulturális ismereteit, és a saját és mások értékrendje közötti kapcsolatok felismerésének képességét. Ezek a kompetenciák szükségesek ahhoz, hogy olyan légkörben folyjék a nevelés-oktatás, ami felkészíti a diákokat az európai együttélésre és együttműködésre. Az Egyesült Államokban is nagy figyelmet szentelnek a pedagógusjelöltek multikulturális kompetenciáinak fejlesztésére (NCATE standards). Erre azért is van szükség, mert az etnikai és kisebbségi tanulók száma 2020-ra el fogja érni az össz-diáklétszám 50\%-át, míg pedagógusok között jelenleg mindössze 10-12\% képviseli a kisebbségi kultúrákat (Peregoy és Boyle, 2008). Az oktatás és nevelés reformjához, a befogadó és esélyegyenlöségre épülő iskolarendszer megteremtéséhez elengedhetetlen feltétel, hogy a pedagógusok rendelkezzenek multikulturális kompetenciákkal.

Ez az írás egy amerikai pedagógusképzőben alkalmazott multikulturális irodalmi projektet mutat be. A transzformatív tanulási elméletre épülő projekt lehetőséget adott a hallgatóknak arra, hogy a művek olvasása közben és után, perszonális narrációban gondolják végig nézeteiket az adott kultúráról, és az ehhez kapcsolódó pedagógusi feladatokról. A cikk először áttekinti az elméleti hátteret, azaz a transz- 
formatív tanulási elméletet, az egyéni tájképet, az autentikus multikulturális irodalom jellemzőit és a perszonális narrációt. Majd a projekt bemutatását a hallgatók reflektív írásaiból vett részletek elemzése, illetve az ezek alapján megfogalmazott következtetések zárják.

\section{A multikulturális irodalmi projekt elméleti háttere}

\section{Transzformativ tanulási elmélet}

Milyen élményekhez kell a pedagógusjelölteket juttatni ahhoz, hogy rendelkezzenek a befogadó és esélyegyenlőséget biztosító környezet megteremtéséhez és fenntartásához szükséges ismeretekkel, készségekkel és hozzáállással? Hogyan történik az ember gondolkodásában a fejlődés, átalakulás és a változás? Az első lépés a transzformáció folyamatában az, amikor tudatosan megvizsgáljuk saját értékrendszerünket, gondolkodásmódunkat, és felismerjük, hogy milyen élmények, tapasztalatok vagy azok hiánya gátol meg a valóság árnyaltabb érzékelésében és megismerésében. Mezirow (1995) azt vallja, hogy a transzformatív tanulás a kognitív egyensúlyi helyzet kibillenéséből ered, és a gondolkodásban bekövetkező változás, azaz a transzformáció akkor jön létre, amikor egy élményt először meghökkentő dilemmaként érzékelünk, majd az azt követö kritikai reflexió segítségével új értelmet nyerünk erröl az élményről. Ennek alapján a következőképpen határozza meg a tanulást: „folyamat, amelyben egy korábbi interpretációt használunk arra, hogy az élmény vagy tapasztalat olyan új értelmezését fedezzük fel, amely a jövőben irányítja és alakítja tetteinket". (Mezirow, 1995, 49. o.). Ezzel összhangban a transzformatív tanulási folyamat három fontos eleme: (1) a megismerés hosszantartó hatása, (2) perszonális narráció használata az önvizsgálat folyamatában, és (3) magatartásbeli változások, mivel a megismerés hatására a tanuló jövőbeli cselekedetei is változnak (Wilson, Switzer, Parrish és IDEAL Research Lab, 2006).

\section{Egyéni tájkép: Felismerés}

Greene (1994) az „egyéni tájkép” kifejezést használja a személyes tudásunk, élményeink és nézeteink összességére. Ezt a metaforát továbbfüzve az esetleges elöítéleteket az „egyéni tájkép fekete foltjainak” vizualizálja. Ezek azt jelképezik, hogy az élmények hiánya vagy az azokon való elgondolkodás mellőzése miatt a félreértések és/vagy az elöítéletek ,fekete foltjai” megszilárdulhatnak az egyéni tájképben, azaz bizonyos fogalmakat, jelenségeket nem is érzékelünk. Greene megjegyzi: ,... ahhoz, hogy harmóniát alakítsunk ki magunk és mások között, fel kell ismernünk saját 'tájképünk' horizontjait, és a benne létező esetleges 'fekete foltokat'. ... Azt javaslom, hogy a pedagógusok törjenek ki egyszólamú nézetvilágukból, és ébredjenek rá a pluralizmusra, fedezzék fel a létezés sokszínúségét és formáit, és azt, hogy menynyi lehetséges módon lehet szemlélni a világot" (Greene, 1994, 21. o.). 
Autentikus multikulturális irodalom: élmények

Az autentikus multikulturális irodalomnak többféle definíciója közül ebben az írásban Short és Fox (2003) meghatározását követjük, amely szerint az autentikus multikulturális irodalom tükrözi a kultúra értékrendjét, tényeit és gondolatvilágát. Ily módon ablakot nyit adott kultúra mélyebb rétegeinek feltárásához, és ezáltal az olvasó a maga olvasatát, értelmezését alakíthatja ki. Az ilyen irodalom sokdimenziós, árnyalt értelmezést ajánl a másságról és a kultúrák értékrendjének sokszínűségéről (Banks, 2006, Sleeter és Grant, 1999). Ezek a jellemzők teszik lehetővé, hogy az olvasó, jelen esetben a pedagógusjelölt elgondolkodjék saját identitásán, és képessé váljék a sajátjától eltérő identitással való azonosulásra. Továbbá, amikor kérdéses, számára ismeretlen és sokszor szinte zavaró gondolatokkal találkozik, ösztönözve érezze magát arra, hogy átvizsgálja saját „egyéni tájképét”, újabb perspektívákat gondoljon végig, és ezáltal nézeteiben, valamint pedagógiai gyakorlatában megkezdődjék a transzformációs folyamat.

\section{Perszonális narráció}

Cassidy szerint az élményeinken való elmélkedés, azaz a személyes kritikai reflexió hozzásegít az információ mélyebb feldolgozásához. „Élményeinken, tapasztalatainkon keresztül gyarapítjuk tudásunkat, és ezeket perszonális narrációban fejezzük ki. A narráció elősegíti azt a folyamatot, amikor igazi értelmet adunk élményeinknek, és ez azt eredményezi, hogy az ismeretet egy újonnan kialakított kontextusban tároljuk az agyunkban" (Cassidy, 2001, 22. o,) Továbbá Cassidy azt is hozzáfüzi, hogy a transzformatív tanulási folyamatban az összegzés elengedhetetlen lépés afelé, hogy a jelenség újonnan kidolgozott értelmezése asszimilálódjék, és a későbbiekben felhasználásra kerüljön.

Mindezek alapján a pedagógusképzésben oktatóknak az a feladata, hogy olyan élményekhez juttassák a jövő pedagógusait, amelyekben szembesülnek addig nem ismert tényekkel, érzésekkel. Ezek a sokszor megdöbbentő és meghökkentő élmények kimozdítják a hallgatókat a mindennapokban használt viszonyítási pontjaikból, és gondolkodásmódjukban hosszantartó hatást idéznek elő, ami pedagógiai gyakorlatukat is módosítja. Amikor a pedagógusjelöltek a multikulturális irodalomban eddig számukra ismeretlen jelenséggel találkoznak, és ezeket az élményeket perszonális narrációban dolgozzák fel, akkor multikulturális kompetenciájuk gazdagodik.

\section{Multikulturális irodalom projekt a pedagógusképzésben}

Egy floridai pedagógusképző program egyik kurzusában, amely elsősorban a kultúrák, a család és az oktatás helyzetét és összefonódását vizsgálta, egy többhetes multikulturális irodalmi projektet iktattunk be. 45 óvodapedagógus, tanító és gyógype- 
dagógus hallgató vett részt a projektben, és azt reméltük, hogy a projekt eredményeként a pedagógusjelöltek kultúrák iránti érzékenysége és interkulturális kompetenciája elmélyül.

A multikulturális irodalmi projekt egyik fő jellegzetessége az volt, hogy minden kultúrához három különböző olvasóréteget - gyermek, ifjúsági és felnőtt - célzó irodalmi müveket választottunk ki. Ezt az indokolta, hogy az eredetileg megcélzott olvasók eltérő kognitív érettsége, háttérismerete és élményanyaga alapján a müvek más mélységben és összetettségben tárták fel a kultúrákhoz kapcsolódó értékeket, konfliktusokat és élethelyzeteket. Továbbá, azt a nyolc kisebbségi kultúrát - mexikói, kubai, afrikai-amerikai, puerto ricói, haiti, guatemalai, muszlim és a koreai választottuk ki, amelyek Floridában a legmeghatározóbbak. Így a hallgatók valószínüleg találkozni fognak ezekkel a kultúrákkal eljövendő osztályaikban. Ezek után a multikulturális irodalmi müvek minőségét értékeltük a már korábban leírt autentikus multikulturális irodalom kritériumai alapján. (Az 1. melléklet tartalmazza a nyolc kultúrát és a kultúrát hitelesen tükröző három irodalmi müvet.)

A héthetes projekt számos tevékenységből épült fel. Minden hallgató választott egy kultúrát, lehetőleg azt, amelyikről a legkevesebb ismerete volt. Elöször egy fogalomtérképet készített (Correa, Hudson és Hymes, 2004), ami a hallgató tudásának írásos és rajzos ábrázolása az adott kultúráról. Az utasítás szerint, ha a kultúrának volt olyan fontos komponense, amiről a hallgatónak nem volt ismerete, például vallás, nyelv, időfogalom, azt kérdőjellel jelezte a fogalomtérképen. Ez a fogalomtérkép dokumentálta, hogy az irodalmi projekt megkezdésekor a hallgató milyen mélységü és összetettségü ismeretekkel és nézetekkel vagy azok hiányával, esetleg sztereotípiákkal rendelkezett.

Az elkövetkező másfél hónapban a hallgató elolvasta a választott kultúra három irodalmi müvét, miközben egy kéthasábos reflektív naplót vezetett: egyik hasáb a kiválasztott mü részleteit, míg a másik az arra vonatkozó reflexiókat tartalmazta. Miután mindhárom könyvet elolvasta, írt egy perszonális narrációt. Néhány megadott gondolatébresztő kérdés ösztönözte a hallgatót arra, hogy kifejtse, mennyiben befolyásolták az olvasottak a kultúrával kapcsolatos ismereteit, nézeteit. Majd ismét elkészítette a fogalomtérképet, ami vizuálisan is kifejezte „,egyéni tájképének” változását (Greene, 1994). Legutolsó lépésként a pedagógusjelöltek egy nagycsoportos reflektív beszélgetés során megosztották egymással a megélt felismeréseket, a gondolataikat, és megvitatták a felmerülö kérdéseket és kételyeket.

\section{A projekt hatása: elemzési módszerek}

A multikulturális irodalmi projekt kísérleti jellege megkívánta, hogy megvizsgáljuk az újszerü pedagógiai megközelítés hatékonyságát. A projekt célja az volt, hogy az irodalmon keresztül a pedagógusjelöltek részt vegyenek egy mélyebb megismerési folyamatban, és ez hosszantartó hatást gyakoroljon interkulturális kompetenciáik 
fejlődésére. A projekt adatainak elemzésével arra kerestük a választ, hogy az irodalmi müvek és a kritikai reflexió megnövelte-e a hallgatók ismereteit, érzékenységét, és társadalmi felelősségtudatát, amit majd pedagógusként a gyakorlatban is demonstrálhatnak.

A fogalomtérképeket aszerint vizsgáltuk, hogy a hallgató kultúráról alkotott koncepciója mennyiben tükrözi a kultúra felszíni/külsődleges jellegzetességeit (például étkezés, zene, népviselet), illetve mennyiben a kultúra mélyebb rétegeit (például értékek, időfogalom, családról alkotott nézeteket, vallás). A kéthasábos reflektív naplót, a perszonális narrációt, valamint a nagycsoportos reflektív beszélgetésből származó feljegyzéseket kvalitatív módszerrel elemeztük, azaz a transzformatív tanulási elmélet kulcskoncepcióinak felbukkanását, meglétét vagy annak hiányát vizsgáltuk (Clandinin és Connelly, 1999).

\section{A pedagógusjelöltek kulturális transzformációja}

\section{Fogalomtérkép}

A fogalomtérképek elemzése azt mutatta, hogy a multikulturális irodalom projekt elmélyítette a hallgatók kultúráról alkotott koncepcióját, és a projektnek köszönhetően a kultúra felszíni jellegzetességei helyett a lényegi, mélyebb kulturális értékazonosságokat és eltéréseket tartották fontosnak. A projekt elkezdésekor az első fogalomtérképeken, a kultúra felszíni és mélyebb rétegeinek jelölése körülbelül azonos számban volt jelen. Továbbá egyértelmü ismerethiány, gyakran sztereotípiák voltak fellelhetők. Még a jól ismert kultúrák is, mint például a mexikói, főként felszíni elemekkel (taco, fiesta, sombrero...) jelent meg, míg a kevésbé ismert, pl. muszlim és a koreai kultúra kapcsán a nagyszámú kérdőjel fejezte ki az ismeretek hiányát.

A projekt végén elkészített fogalomtérképeken a kultúra már jóval kevesebb felszíni jellegzetességgel volt ábrázolva, és jelentősen megnőtt a kultúra mélyebb rétegeinek a jelölése. A kérdőjelek száma is jelentősen csökkent. Ezek alapján úgy tủnik, hogy a három könyv olvasása a többszintü reflektív tevékenységgel azt eredményezte, hogy a hallgatók felismerték, hogy a kultúrák lényegi jellegzetességei nem a felszínes vagy külsődleges vonások, hanem a mélyebb rétegeket kifejező értékek, gondolkodásmód és viszonyulások. Ez már arra utal, hogy a projekt hatására a hallgatók megtapasztalták a gondolkodásukban megjelenő átalakulást.

Reflektiv gondolatok: a táguló „egyéni tájkép”

A multikulturális irodalom olvasását követő kéthasábos reflektív napló, a perszonális narráció és a nagycsoportos reflektív beszélgetés elemzése azt mutatja, hogy a hallgatók (1) hosszantartó élményanyagot szereztek az új kultúráról, (2) saját kultúrájukról való nézeteiket átformálták, (3) felismerték a további ismeretszerzés fontosságát, és 
(4) kifejezték szándékukat arra, hogy majd munkájuk során egy, a kultúrákat befogadó tanítási környezetet fognak kialakítani.

\section{Hosszantartó élményanyag megszerzése az új kultúráról}

A pedagógusjelöltek új ismereteket szereztek az adott kultúráról. Részletesen megvitatták a kultúra mélyebb rétegeit kifejező értékeket, jellegzetességeket, mint például az idősek tiszteletét, a tanulás fontosságát, a munkamorált, az identitástudatot és a családban és közösségben történő tanulást. Az egyik hallgató rámutatott a mexikói-amerikai családok értékrendjére: „Ez a könyv rányitotta a szemem, hogy milyen is a család szerkezete, és rájöttem, hogy a családtagok nemcsak törödnek egymással, de kemény munkával támogatják is egymást." (Mex $\left.{ }^{1}\right)$ Hasonlóan egy másik hallgató kifejtette, hogy a család értékrendje határozza meg a mindennapokat: „, $A \mathrm{ku}$ bai-amerikai családokban nagyon magas a munkamorál, amit a gyerekeiktöl is elvárnak. " (Kuba) Továbbá a hallgatók leírták, hogy a könyvek betekintést nyújtottak a más kultúrákba tartozók életérzésébe, ami számukra eddig ismeretlen volt: „Csak most jöttem rá, hogy sok gyerek, aki elhagyja hazáját, és Amerikában folytatja az életét, gyakran úgy érzi, hogy a két kultúra fogságába esett." (Puerto Rico) Számos hallgató nyíltan írt arról, hogy a könyvekből szerzett új ismeretek arra késztették őket, hogy átgondolják sztereotípiáikat és megszabaduljanak tőlük: „,Korábban azt gondoltam, hogy a mohamedánok mind terroristák, akik barbár viszonyok közt élnek. Mikor elkezdtem ezt a projektet, biztos voltam abban, hogy ez a nézetem majd megerösitésre kerül. Most, mikor végiggondolom, hogy mit is tanultam ebben a projektben, rájövök, mennyire tévedtem. Örülök, hogy nem volt igazam, és már nem hiszek a korábbi nézetemben. Mostantól, ha látok egy mohamedán nöt hijab-bal (kendö) a fején, tudni fogom, hogy ez egyszerüen a vallási hovatartozását jelöli, és nem azt, hogy egy férfiak által uralt terrorista csoport tagja." (Musl)

\section{Saját kultúrájukról való nézeteik átformálása}

A multikulturális irodalom olvasása arra ösztönözte a hallgatókat, hogy saját kultúrájukat, identitásukat is átgondolták, ami önmagukról és másokról is mélyebb, tudatosabb megértést eredményezett. Felfedezték a hasonlóságokat a kultúrák között, amit egyikük így fejezett ki: „Ezeket a könyveket olvasva rájöttem, hogy mennyi hasonlóság van a különbözö kultúrák értékrendje között, például a család fontossága. Mindez arra utal, még ha más-más kultúrához tartozunk is, sok minden közös bennünk. ” (Mex) Ugyanakkor arra is utaltak, hogy a könyvek ráirányították figyelmüket az egyes kultúrán belüli változatosságra és azok fontosságára is: ,, Megértettem, hogy nem lehetnek megalapozatlan feltevéseim. Hiszen még az a diák is, aki ugyanabból a kultúrából való, mint én, talán egészen más élményekben és neveltetésben része-

\footnotetext{
${ }^{1}$ A zárójelben a rövidítés jelöli, hogy melyik kultúráról olvasott a hallgató, akitől az idézet származik
} 
sült. A gyökerek lehetnek ugyanazok, de más-más életek erednek a gyökerekböl, és jövendőbeli tanárként fontos megjegyeznem, hogy minden gyerek egyéniség, aki saját életélménnyel és egyéni tudással rendelkezik." (AfriAmer) Továbbá, az eddig elöitélettel szemlélt muszlim kultúra is új perspektívába került a két kultúra értékeiben felfedezett hasonlóságok alapján. Az egyik pedagógusjelölt megjegyezte, „Miután elolvastam a könyveket, már képes vagyok kapcsolatot találni a muszlim és saját kultúrám között. Rádöbbentem, hogy nem is élnek teljesen más világban, és sokkal több hasonlóság van köztük és köztem, mint gondoltam." (Musl)

\section{További ismeretek gyarapitásának fontossága}

A multikulturális irodalmi projektben való részvétel további tanulásra, a kultúrák alaposabb megismerésére, felfedezésére sarkallta a hallgatókat. Személyes narratívájukban leírták, ahogyan a könyvek ablakot nyitottak a kultúrára, és hogy megtapasztalták a további felfedezés korlátlan lehetőségeit: „,Ezek a könyvek rávilágítottak arra, hogy a kultúrák mennyire különböznek egymástól. Korábban azt gondoltam, hogy sokat tudok a kultúrákról, de most meg kellett értenem, hogy mennyi mindennek nem voltam tudatában. Habár úgy érzem, sokat tanultam ebben a projektben, azt is be kell ismernem, hogy leginkább arra eszméltem rá, hogy mennyi mindent kell még megtanulnom." (AfriAmer) Hasonlóan egy másik hallgató elmondta, hogy „Igaz a könyvek sok mindent feltártak a haiti nyelvröl és kultúráról, de még sokkal többet kell erröl tudnom, hogy igazán jó tanár lehessek.” (Haiti)

\section{Szándék a befogadó tanitási környezet kialakitására}

A pedagógusjelöltek a könyvekből nyert ismereteket és élményeket arra használták, hogy eljövendő hivatásukra vonatkozó gyakorlati ötleteket, stratégiákat fogalmaztak meg. A következő idézetek jelzik, hogy a pedagóguspályára való készülödésüket mi módon gazdagította a multikulturális irodalom olvasása: „Megértö leszek, ha a gyerekek az osztályomban az Ebonics²-ot beszélik. Nem fogom megakadályozni, hogy használják ezt a nyelvváltozatot, ami számukra az anyanyelv, sokszor hovatartozásuk kifejezője. Ugyanakkor elmagyarázom nekik, hogy az iskolában meg kell tanulniuk az irodalmi angol nyelvet is, hiszen késöbbi tanulmányaik során ezt használják szóban és írásban.” Egy másik hallgató a gyerekek érzelmi állapotára utalt, mikor lejegyezte „Emlékezni fogok, hogy vannak olyan gyerekek, akik elszakadnak a családjuktól, nagyszülöktöl, amikor ebbe az országba emigrálnak. Például, a Kubából érkezettek, gyakran szeretteiktől távol élnek, elszakadva, ami bizony súlyos érzelmi megterhelést jelenthet." (Kuba) Egy másik hallgató a következő stratégiát fogalmazta meg, „Pedagógusként fontos tudnom, hogy a gyerekek etnikai-kulturális háttere iránt érzett elismerésemet és tiszteletemet azzal is ki tu-

\footnotetext{
${ }^{2}$ az angol nyelv dialektusa, amit az afrikai-amerikai csoportok használnak
} 
dom fejezni, hogy a diákjaim nevét nem amerikanizálom, és Juant nem hívom Johnnak. Azzal, hogy a szüleiktöl kapott nevüket helyesen ejtem ki, hidat fogok épiteni az otthon és az iskola közé, hogy a gyereknek ne kelljen azon gondolkodnia ,ki is vagyok én?" Így a diákok büszkék lehetnek kulturális hátterükre, miközben beilleszkednek az új életükbe egy új országban." (Haiti)

Ezek a pedagógia stratégiák, megközelítések azt mutatják, hogy a projektben résztvevő hallgatók jelentős lépést tettek a pedagógusoktól elvárt multikulturális kompetenciák irányába.

\section{Záró gondolatok}

Számos kérdés merül fel a pedagógusképzésben arról, hogy a hallgatók mennyire felkészültek a befogadó környezet megteremtésére és fenntartására. Honnan is tudjuk, hogy a pedagógusjelöltek megnyitották-e azt a bizonyos ablakot, amin keresztül elöítéletek nélkül képesek megközelíteni a kultúrák, képességek, nyelvek sokszínűségét, amit a diákok reprezentálnak az iskolai osztályokban? Honnan tudjuk, hogy a transzformáció megindult gondolkodásukban, és egyre kevesebb „fekete folt” van az „egyéni tájképükben”?

Az itt bemutatott projekt elemzése azt sugallja, hogy amikor pedagógushallgatók lehetőséget kapnak az autentikus multikulturális irodalom olvasására és perszonális narráció írására, a változások, azaz a transzformatív tanulási folyamat jelei nyomon követhetök. Az itt részt vevő hallgatók kifejezték, hogy az új kultúráról tudásuk és ismereteik jelentősen növekedett. Ezt a gyarapodást, ami sokkal inkább minőségi változás, mint mennyiségi, az támasztja alá hitelesen, ahogyan a kultúrák és a másság mélyebb, lényegesebb rétegei kapcsán a pedagógusjelöltek boncolgatták saját változó szerepüket, mint jövendő tanárok. Reflektív írásaik jelzik társadalmi és szociális felelősségérzésük gazdagodását, amikor a befogadó tanítási és tanulási környezet kialakítását tervezgetik. Összességében, a hallgatók sokrétegü multikulturális képességeket fejlesztettek ki, és azokat alkalmazták az identitásuk vizsgálatára és jövendő szerepük, felelősségük tervezgetésében. Ezek a kibontakozó képességek összecsengenek mind az Egyesült Államokban, mind az Európai Unióban kidolgozott és elvárt tanári kompetenciákkal.

\section{Irodalom}

Banks, J. A. (2006): Cultural diversity and education: Foundations, curriculum, and teaching (5th ed.). New York: Pearson Education Inc.

Cassidy, K. (2001): Enhancing your experiential program with narrative theory. Journal of Experiential Education, 24 (1), 22-27.

Clandinin, J., Connely, M. (2000): Narrative inquiry: Experience and story in qualitative research. San Fransisco: Jossey-Bass A Wiley Company. 
Correa, V. I., Hudson, R. F., Hayes, M. T. (2004): Preparing early childhood special educators to serve culturally and linguistically diverse children and families: Can a multicultural education course make a difference? Teacher Education and Special Education: The Journal of the Teacher Education Division of the Council for Exceptional Children, 27 (4), 323-341.

European Commission (2005): Common European principles for teacher competences and qualifications. http://ec.europa.eu/education/policies/2010/doc/principles_en.pdf

Greene, M. (1994): Multiculturalism, community, and the arts. In: Dyson, A., Genishi, C. (Eds.): The need for story: Cultural diversity in classroom and community. Urbana, Illinois: NCTE 11-27.

Mezirow, J. (1995): Transformation theory of adult learning. In: In defense of the lifeworld, Welton, M. (Ed.). 39-70. New York: SUNY Press.

NCATE Standards. National Council for Accreditation of Teacher Education. Retrieved http://www.ncate.org/public/unitStandardsRubrics.asp?ch=4

Peregoy, S. F., Boyle, O. F. (2008): Reading, writing, \& learning in ESL: A resource book for $K-12$ teachers $\left(5^{\text {th }}\right.$ ed.). New York: Allyn \& Bacon.

Short, K. G., Fox, D. L. (2003): The sociopolitical contexts of cultural authenticity. Ill: National Council of Teachers of English.

Sleeter, C. E. Grant, C. A. (1999): Making choices for multicultural education: Five approaches to race, class, and gender ( $3^{\text {rd }}$ ed.). New York: Merrill.

Wilson, B. G., Switzer, S. H., Parrish, P., IDEAL Research Lab. (2006): Transformative learning experiences: How do we get students deeply engaged for lasting change? Proceedings of AECT 2006.

http://thunder1.cudenver.edu/ideal/docs/AECT06ProceedingsRevised.doc 


\section{MELLÉKLET}

\begin{tabular}{|c|c|c|c|}
\hline Kultúra & Gyermekirodalom & Ifjúsági irodalom & Felnött irodalom \\
\hline mexikói & $\begin{array}{l}\text { Amelia's road, } \\
\text { Altman, L. }\end{array}$ & $\begin{array}{l}\text { The circuit, } \\
\text { Jimenez, F. }\end{array}$ & $\begin{array}{l}\text { Caramelo, } \\
\text { Cisneros, } \mathrm{S} .\end{array}$ \\
\hline kubai & $\begin{array}{l}\text { Cuban kids, } \\
\text { Ancona, G. }\end{array}$ & $\begin{array}{l}\text { Where the flame trees } \\
\text { bloom, Flor Ada, A. }\end{array}$ & $\begin{array}{l}\text { Dreaming in Cuban, } \\
\text { Garcia, C. }\end{array}$ \\
\hline koreai & $\begin{array}{l}\text { Dear Juno, } \\
\text { Pak, S. }\end{array}$ & $\begin{array}{l}\text { When my name was } \\
\text { Keoko, Park, L. }\end{array}$ & $\begin{array}{l}\text { A step from heaven, } \\
\mathrm{Na}, \mathrm{A} .\end{array}$ \\
\hline $\begin{array}{l}\text { afrikai- } \\
\text { amerikai }\end{array}$ & $\begin{array}{l}\text { The other side, } \\
\text { Woodson, J. }\end{array}$ & $\begin{array}{l}\text { The house you pass on } \\
\text { the way, Woodson, J. }\end{array}$ & $\begin{array}{l}\text { The color of water, } \\
\text { McBride, J. }\end{array}$ \\
\hline muszlim & $\begin{array}{l}\text { The librarian of Basra, } \\
\text { Winters, J. }\end{array}$ & $\begin{array}{l}\text { Magid fasts for } \\
\text { Ramadan, } \\
\text { Matthews, M. }\end{array}$ & $\begin{array}{l}\text { Thura's diary, My life } \\
\text { in wartime Iraq, } \\
\text { al-Windawi, T. }\end{array}$ \\
\hline puerto ricoi & $\begin{array}{l}\text { A golden flower: } \\
\text { A Taíno myth from } \\
\text { Puerto Rico, Jaffe, N. }\end{array}$ & $\begin{array}{l}\text { An island like you: } \\
\text { Stories of the Barrio, } \\
\text { Coffer, J. }\end{array}$ & $\begin{array}{l}\text { Almost a woman, } \\
\text { Santiago, E. }\end{array}$ \\
\hline haiti & $\begin{array}{l}\text { Josiah, hold the book, } \\
\text { Elvgren, J. }\end{array}$ & $\begin{array}{l}\text { The scorpion's claw, } \\
\text { Chancy, M. }\end{array}$ & $\begin{array}{l}\text { Tonight by sea, } \\
\text { Temple, F. }\end{array}$ \\
\hline guatemalai & $\begin{array}{l}\text { Sawdust carpets, } \\
\text { Carling, A. }\end{array}$ & $\begin{array}{l}\text { Tree Girl, } \\
\text { Mikaelsen, B. }\end{array}$ & $\begin{array}{l}\text { Hummingbird House, } \\
\text { Henley, P. }\end{array}$ \\
\hline
\end{tabular}

